\title{
Assessment of Genetic Diversity in Different Chilli (Capsicum annuum L.) Genotypes
}

\author{
S.C. Nahak ${ }^{1}$, A. Nandi ${ }^{2}$, G.S. Sahu ${ }^{1}$, P. Tripathy ${ }^{1}$, S. Das ${ }^{2}$, \\ A. Mohanty ${ }^{2}$ and S.R. Pradhan ${ }^{*}$ \\ ${ }^{1}$ Department of Vegetable Science, College of Agriculture, OUAT, \\ Bhubaneswar-751003, India \\ ${ }^{2}$ AICRP Vegetable Crops, OUAT, Bhubaneswar-751003, India \\ *Corresponding author
}

\begin{abstract}
A B S T R A C T
Keywords

Chilli, Genetic

divergence, Cluster

analysis, $\mathrm{D}^{2}$ statistics

Article Info

Accepted:

06 August 2018

Available Online:

10 September 2018

Eleven genotypes of chilli (Capsicum annuum L.) were investigated to understand the extent of genetic diversity through 16 growth and yield attributing characters. Genetic diversity in chilli genotypes based on sixteen characters was estimated using Mahalanobis's $\mathrm{D}^{2}$ statistics. The genotypes were grouped into four different clusters by non-hierarchical clustering. The cluster I had the maximum number (7) of genotypes while cluster III and IV each contained only one genotype. Cluster II and III had highest inter cluster distance (249.759) followed by cluster III and IV (239.433). It was also observed that the contribution of fruit yield per plant to genetic divergence of genotypes in chilli was the maximum followed by leaf curl/plot and fruit weight. So, selection of parents differing in these quantitative traits may be proved useful for heterosis breeding programme in chilli.
\end{abstract}

\section{Introduction}

Chilli (Capsicum annum L.) is a member of the Solanaceae family, originated from South and Central America. It is one of the most important spice crop worldwide, with a global production 30.71 lakh tonnes and 20.378 lakh ha area harvested, in 2010-11. In India chilli ranked first in spice crops in terms of production (12.23 lakh tonnes) and area harvested (7.92 lakh ha), in the year 2010-11 (FAOSTAT, 2012). The primary centre of origin of chilli is said to be Mexico with secondary centre in Guatemala and Bulgaria (Salvador, 2002). It was introduced in Europe by Columbus in the 15th century and spread to rest of the world along the spice trading routes to Africa, India, China and Japan. Chilli was introduced in southern India by the Portuguese from Brazil in the middle of 17th century and cultivation spread throughout India by the end of the 19th century. Due to long history of cultivation, selection and popularity of crops, sufficient genetic variability has been generated. Rich variability in morphological traits in hot pepper occurs throughout India, particularly in south peninsular region, North Eastern foot hills of Himalayas and Gangetic plains (Pradheep and Veeraragavatham, 2006). However, the high variability present in the 
crop has so far not been fully exploited in the crop improvement programmes.

Genetic diversity is the basic requirement for any successful breeding programme. Assessment of genetic diversity among germplasms is a prerequisite for plant breeders in choosing potential parental lines because of two reasons: i.e., (i) In the hybridization programme, genetically diverse parents likely to produce high heterotic effect, and (ii) Genetically distant parents could produce a wide spectrum of variability in the segregating generation. Therefore, a clear characterization of germplasms is the first step to facilitate successful breeding efforts.

The degree of genetic divergence can be quantified using Mohalanobis's $D^{2}$ statistic of multivariate analysis which is recognized as a powerful tool for assessing the relative contribution of different characters to the total divergence in self-pollinated crops (Golakia and Makne 1992; Natarajan et al., 1988; Das and Gupta 1984; Shidhu et al., 1989). Therefore, the present study was undertaken to assess the genetic diversity in 13 genotypes of chilli to identify suitable genotypes.

\section{Materials and Methods}

The study was carried out at All India Coordinated Research Project on Vegetable Crops, O.U.A.T, Bhubaneswar during rabi season of 2016 in a randomized block design with three replications to evaluate most promising genotypes with respect to the quality parameters among the 11 genotypes of chilli. Each genotype was raised in $8.1 \mathrm{~m} 2$ area with a spacing of $50 \mathrm{~cm} \mathrm{x} 30 \mathrm{~cm}$ accommodating 54 plants per plot. The crop was grown with standard package of practices. The observations were recorded on sixteen economic traits from five randomly selected competitive plants from each genotypes and replication. Mahalanobis (1928) generalized distance, $\mathrm{D}^{2}$ - statistic was used for computing genetic divergence as described by Rao (1952). The original measurements were transformed to standardized uncorrelated variables by pivotal condensation (Rao, 1952). The divergence between any two varieties was obtained as the sum of squares of the difference in the values of the corresponding transformed values of the corresponding transformed values $\left(\mathrm{V}_{\mathrm{ij}}\right)$. Following Tocher's method as described by Rao (1952), the genotypes were grouped into clusters. The criterion of grouping was that any two genotypes belonging to the same cluster should have a smaller $\mathrm{D}^{2}$ value than those between genotypes belonging to different clusters. Inter and intra-cluster distances were determined and represented.

\section{Results and Discussion}

The data of varietal trial on chilli (Mean performance of the varieties are present in Table 1) were subjected to further analysis of genetic divergence. The multivariate analysis based on Mahalanobis' $\mathrm{D}^{2}$ statistics is being employed as a powerful tool for measuring genetic divergence among the tested genotypes. Ramanujan et al., (1974) have categorically suggested the merits of $\mathrm{D}^{2}$ statistics for genetic grouping of germplasm. In the present investigation, the grouping by multivariate technique has shown good results. Being a numerical estimate, the multivariate technique has the added advantage over other criteria of permitting precise comparison among all possible pairs of population in any given group. Since, the estimates are obtained from study of potential parents themselves, the required information is available before deciding parents for future recombination breeding, thus, can be used with advantage. It is well established that hybrid derivatives from divergent parents are found to be promising, probably because of complementary interaction of divergent genes 
in the parents taken for cross in the parents. A perusal of Table 2 shows that the 11 genotypes of chilli could be grouped into 4 clusters on the basis of intra and inter cluster distances. The first cluster I comprised of 7 genotypes, cluster II consisted of 2 genotypes, while cluster III and IV consisted of 1 genotype each. Cluster II and III had highest inter cluster distance followed by cluster III and IV.

Cluster I had the highest mean value for plant height. Cluster III recorded the highest mean values for fruit length, fruit girth, fruit weight, leaf area, initial flowering, 50\% flowering, fruit borer (no. of fruits/ plant), leaf curl (no. of plants/plot) and wilting(no. of plants/plot). Cluster IV had the highest mean values for branches/plant, plant spread (E-W), plant spread (N-S), no. of fruits/plant, anthracnose (no. of fruits/plant), fruit yield/plant.

Relative contribution of fruit yield per plant to genetic divergence of genotypes in chilli was the maximum, followed by leaf curl/plot and fruit weight. In the present study, Cluster II and III had highest inter cluster distance followed by cluster III and IV. So, promising hybrid derivatives can be obtained by crossing the parents selected from these two divergent groups (Table 3-5).

Table.1 Mean performance of different genotypes in chilli (Pooled)

\begin{tabular}{|c|c|c|c|c|c|c|c|c|c|c|c|c|c|}
\hline Genotypes & PH & BP & PSEW & PSNS & LA & DIF & DFF & FW & FL & FG & NFP & FYP & YQH \\
\hline 2014/CHIVAR-2 & 91.47 & 14.00 & 57.10 & 48.07 & 22.28 & 43.83 & 53.50 & 5.31 & 9.29 & 3.61 & 54.75 & 146.14 & 76.26 \\
\hline 2014/CHIVAR-3 & 79.72 & 12.83 & 55.05 & 52.35 & 22.99 & 37.00 & 55.17 & 4.57 & 9.16 & 3.37 & 63.29 & 150.99 & 91.93 \\
\hline 2014/CHIVAR-4 & 79.01 & 12.00 & 51.50 & 45.83 & 22.20 & 26.33 & 42.17 & 7.18 & 9.00 & 3.78 & 31.04 & 149.12 & 70.09 \\
\hline 2014/CHIVAR-5 & 83.40 & 13.00 & 54.20 & 52.14 & 21.32 & 42.17 & 52.17 & 4.50 & 8.62 & 3.27 & 37.91 & 53.13 & 36.16 \\
\hline 2014/CHIVAR-6 & 71.20 & 13.00 & 49.83 & 43.31 & 25.58 & 52.83 & 61.17 & 6.21 & 8.79 & 4.12 & 45.60 & 126.51 & 73.30 \\
\hline 2014/CHIVAR-7 & 81.37 & 13.67 & 55.00 & 44.91 & 23.41 & 32.33 & 47.00 & 8.23 & 10.01 & 3.75 & 52.06 & 161.74 & 103.41 \\
\hline 2014/CHIVAR-8 & 89.80 & 11.00 & 60.13 & 60.13 & 23.82 & 35.83 & 51.83 & 3.78 & 6.53 & 3.30 & 76.55 & 94.82 & 56.76 \\
\hline 2014/CHIVAR-9 & 78.48 & 12.67 & 45.90 & 42.71 & 25.44 & 43.17 & 57.17 & 15.14 & 13.75 & 3.89 & 22.64 & 101.45 & 50.22 \\
\hline 2014/CHIVAR- & 64.73 & 12.83 & 67.47 & 62.08 & 23.54 & 38.50 & 50.50 & 3.95 & 7.17 & 3.42 & 94.85 & 152.12 & 86.26 \\
\hline 10 & 52.97 & 10.00 & 63.62 & 57.80 & 22.25 & 49.50 & 57.33 & 3.18 & 7.64 & 3.33 & 44.21 & 83.19 & 50.35 \\
\hline LCA-2(C) & 92.90 & 12.00 & 63.07 & 54.07 & 18.99 & 34.33 & 44.83 & 3.52 & 7.75 & 3.64 & 65.73 & 48.54 & 55.41 \\
\hline SEm( + (3) & 3.41 & 0.76 & 2.68 & 1.95 & 0.94 & 2.18 & 1.58 & 0.11 & 0.41 & 0.13 & 4.41 & 17.11 & 0.94 \\
\hline CD at 5\% & 7.12 & 1.58 & 5.58 & 4.06 & 1.96 & 4.56 & 3.30 & 0.24 & 0.86 & 0.27 & 9.19 & 50.47 & 2.78 \\
\hline
\end{tabular}

PH-Plant Height (cm), BP- Branches/Plant, FL- Fruit Length (cm), FG- Fruit Girth (cm), FW- Fruit weight (g), LALeaf Area $\left(\mathrm{cm}^{2}\right)$, PSEW - Plant Spread (E-W) $(\mathrm{cm})$, PSNS - Plant Spread (N-S) $(\mathrm{cm})$, DIF- Days Initial Flowering (DAP), DFF- Days 50\% Flowering (DAP), NFP- No. of Fruits/Plant, FYP- Fruit Yield/Plant (g), YQH-Yield (q/ha). 
Table.2 Clustering pattern of 11 genotypes in chilli

\begin{tabular}{|l|c|l|}
\hline Cluster No. & Number of chilli genotypes & \multicolumn{1}{|c|}{ Name of genotypes } \\
\hline I. & 7 & 2014/CHIVAR-2, 2014/CHIVAR-3,2014/CHIVAR-4, 2014/CHIVAR-5, \\
& & 2014/CHIVAR-6, 2014/CHIVAR-7, 2014/CHIVAR-8 \\
\hline II. & 2 & KA-2(C), LCA-334(C) \\
\hline III. & 1 & 2014/CHIVAR-9 \\
\hline IV. & 1 & 2014/CHIVAR-10 \\
\hline
\end{tabular}

Table.3 Intra and inter cluster average $\left(\mathrm{D}^{2}\right)$ and corresponding $\mathrm{D}$ values in (parenthesis) among genotypes

\begin{tabular}{|l|c|c|c|c|}
\hline & I. & II. & III. & IV. \\
\hline I. & 3488.810 & 3500.333 & 43387.320 & 4144.512 \\
\hline II. & $(59.066)$ & $(59.164)$ & $(208.296)$ & $(64.378)$ \\
\hline & & 778.567 & 62379.641 & 2104.354 \\
\hline III. & & $(27.903)$ & $(249.759)$ & $(45.873)$ \\
\hline IV. & & & 0.000 & 57328.309 \\
& & & $(0.000)$ & $(239.433)$ \\
\hline
\end{tabular}

Table. 4 Cluster wise mean values of 16 characters of genotypes in chilli

\begin{tabular}{|c|c|c|c|c|c|c|c|c|c|c|c|c|c|c|c|c|}
\hline & PH & BP & FL & FG & FW & LA & PSEW & $\begin{array}{l}\text { PS- } \\
\text { NS }\end{array}$ & DIF & DFF & NFP & FBP & $\mathbf{A P}$ & LP & $\mathbf{W P}$ & FYP \\
\hline I. & .281 & 6 & 70 & 3601 & & & & 49.5 & & & & & & & & \\
\hline II. & 72.933 & 1.000 & 7.695 & 5 & 0 & Q & 3 & & & & & & & & & \\
\hline III. & 78.483 & 12.667 & 13.750 & 3.887 & 151 & 25. & & & & & & & & & & \\
\hline IV. & 64.733 & 12.833 & 7.173 & 3.417 & 39.530 & 23.537 & 67.467 & 62.080 & 38.500 & 50.500 & 94.847 & 6.337 & 2.570 & 4.333 & 5.667 & 379.043 \\
\hline
\end{tabular}

PH-Plant Height (cm), BP- Branches/Plant, FL- Fruit Length (cm), FG- Fruit Girth $(\mathrm{cm})$, FW- Fruit weight (g), LA- Leaf Area $\left(\mathrm{cm}^{2}\right)$, PSEW - Plant Spread(E-W) $(\mathrm{cm})$, PSNS - Plant Spread (N-S) (cm), DIF- Days Initial Flowering (DAP), DFF- Days 50\% Flowering (DAP), NFP- No. of Fruits/Plant, FBP- Fruit Borer (no. of fruits/ plant), AP- Anthracnose (no. of fruits/plant), LP- Leaf Curl (no. of plants/plot), WP- Wilting (no. of plants/plot), FYP- Fruit Yield/Plant(g). 
Table.5 Relative contribution of different characters to genetic divergence of genotypes in chilli

\begin{tabular}{|l|c|c|}
\hline \multicolumn{1}{|c|}{ Name of Characters } & No of $\mathbf{1}^{\text {st }}$ rank & Percent contribution \\
\hline Plant height(cm) & 0 & 0.0000 \\
\hline Branches/plant & 0 & 0.0000 \\
\hline Fruit length(cm) & 0 & 0.0000 \\
\hline Fruit girth(cm) & 0 & 0.0000 \\
\hline Fruit weight (g) & 4 & 7.2727 \\
\hline Leaf area(cm $\left.{ }^{2}\right)$ & 0 & 0.0000 \\
\hline Plant spread(E-W)(cm) & 0 & 0.0000 \\
\hline Plant spread(N-S)(cm) & 0 & 0.0000 \\
\hline Days initial flowering & 1 & 1.8182 \\
\hline Days 50\% flowering & 0 & 0.0000 \\
\hline No. of fruits/plant & 2 & 3.6364 \\
\hline Fruit borer (no. of fruits/ plant) & 1 & 1.8182 \\
\hline Anthracnose (no. of fruits/plant) & 0 & 0.0000 \\
\hline Leaf curl(no. of plants/plot) & 32 & 23.6364 \\
\hline Wilting(no. of plants/plot) & 55 & 3.6364 \\
\hline Fruit yield/plant(g) & 2 & 58.1818 \\
\hline Total & 0 & 100 \\
\hline
\end{tabular}


In the present study, genotypes obtained from different geographical locations were grouped into a single cluster (Cluster I). Therefore, it is apparent that genetic diversity and geographical diversity do not tally. This is in agreement with the findings of other researchers (Mishra et al., 2011; Hasan et al., 2014; Janaki et al., 2016).

It was also observed that the contribution of fruit yield per plant to genetic divergence of genotypes in chilli was the maximum as was also reported by Hasan et al., (2014). It was followed by leaf curl/plot and fruit weight. So, selection of parents differing in these quantitative traits may be proved useful for heterosis breeding programme in chilli.

\section{References}

Das, P. K., and Gupta, T. D., 1984, Multivariate analysis in blackgram, Indian Journal of Genetics, 44(2): 243247.

FAOSTAT, 2012. http://faostat.fao.org.

Golakia, P. R., and Makne, V. G., 1992, D2 analysis in Varginia runner ground nut genotypes, Indian Journal of Genetics, 55(3): 251-253.

Hasan, M. J., Kulsum, M. U., Ullah, M. Z., Hossain, M. Manzur and Mahmud, M. Eleyash. 2014. Genetic diversity of some chilli (Capsicum annuum L.) genotypes, International Journal of Agricultural Research, Innovation and Technology, 4 (1): 32-35.

Janaki, M., Naidu, L. N., Ramana, C. V. and Rao, M. P., 2016. Genetic divergence among chilli (Capsicum annuиm L.) genotypes based on quantitative and qualitative traits, International Journal of Science and Nature, 7 (1): 181-189.

Mahalanobis, P. C., 1928. On the need for standardization in measurements on the living, Biometrika, 20: 1-31.

Misra, Shrilekha, Lal Raj Kishori, Darokar Mahendra Pandurang, Khanuja Suman Preet Singh. 2011. Genetic variability in germplasm accessions of Capsicum annuum L., American Journal of Plant Sciences, 2: 629-635.

Natarajan, C., Thiyagarajan, K., and Rathanaswary, R., 1988, Association and genetic diversity studies in greengram, The Madras Agricultural Journal, 75(8): 238-245.

Pradheep, K. and Veeraragavathatham, D. 2006. Characterization of Capsicum spp. Germplasm, Indian Journal of Plant Genetic Resources, 19(2): 180183.

Ramanujan, S., Tewari, A. S. and Mehra, R. B., 1974. Genetic divergence and hybrid performance in mung bean, Theoretical and Applied Genetics, 45: 211-214.

Rao, C. R., 1952. Advanced Statistical Methods in Biometric Research. John Wiley Sons, New York, P: 390.

Salvador, M. H., 2002. Genetic resources of chilli (Capsicum annuum L.) Mexico. Proceedings of 16th International conference Tampico, Tamaulipas, Mexico, November. 10-12.

Shidhu, J. S., Ahmed, S., Sing, M. P., and Sing, P. K., 1989, Multivariate analysis in blackgram (Vigna mungo L.), Legume Research, 12(1): 35-37.

\section{How to cite this article:}

Nahak, S.C., A. Nandi, G.S. Sahu, P. Tripathy, S. Das, A. Mohanty and Pradhan, S.R. 2018. Assessment of Genetic Diversity in Different Chilli (Capsicum annuum L.) Genotypes. Int.J.Curr.Microbiol.App.Sci. 7(09): 634-639. doi: https://doi.org/10.20546/ijcmas.2018.709.075 